\title{
Empirical Determinants of Traders Access to Credit in Ghana: Does Educational Literacy Level Matter?
}

\author{
Enock Kojo Ayesu (iD ${ }^{1}$
}

Received: 03.09.2019; Revised: 30.11.2019; Accepted: 18.05.2020

\begin{abstract}
The present study examines the determinants of trader's access to credit in Ghana with a major focus on the educational literacy level of traders. To do so, the study relies mainly on primary data and applies the probit estimation technique to the dataset. The study finds that source of income, collateral security, household size, business experience and educational literacy level is significant in determining traders' access to credit in Ghana. Based on these findings, it is recommended that financial institutions should encourage traders to upgrade their educational literacy level on accounts and records keeping, since this will enhance their basic knowledge not only on their trading activities but also on financial transactions.
\end{abstract}

JEL codes: E51, F10, C25

Keywords: Access to credit, traders, educational literacy level, Probit regression, Ghana

\section{Introduction}

The contribution of traders in the development of economies is largely recognized. They contribute extensively to livelihood activities (income for household), support for families and relatives, job creation, payment of levies and rent, food security and final step for the distribution of consumer goods in both developed and developing countries. Over the years with limited education, skills, and little formal employment openings, households and individuals in developing countries often turn to self- employments (trading) as a means of supporting their families and themselves. However, the high

1 Department of Economics, Kwame Nkrumah University of Science and Technology, Kumasi, Ghana. (e-mail: ayesu.enock@yahoo.com). rate of unemployment due to declining formal sector jobs also explain the increases in the number of people involved in trading activities in developing countries (Mabasa, 2015).

According to World trade organization (Auboin et al., 2016), the existence of a healthy trading system in any economy is dependent on the availability of financial support. They further asserted that up to $80 \%$ of worldwide trade is supported by some sort of financing or credit insurance. However, the challenge faced in accessing credit is that, there are major gaps in delivery and therefore many traders cannot access the monetary tool they need for their trading activities globally (Auboin et al., 2016). Generally, without sufficient trade finance, opportunities for growth and 
development are overlooked; traders are deprived of the fuel they need to trade and expand.

In Africa, it is widely acknowledged that trading activities is the main engine of growth and this cannot be overemphasized. Most of the population are engaged either in petty trading, wholesale or retail trading as a results of limited access to formal employment opportunities. In Ghana, majority of the population are engaged in the Agricultural sector (55.8\%) followed by the trading sector $(15.2 \%)$ (Poku et al., 2008). As of 2015 , according to the integrated business establishment survey and the national employment report, $59.9 \%$ of the population are employed in the informal establishments, with the remaining $40.1 \%$ in the formal sector establishment. However, 817,848 representing $30.2 \%$ of the country's population are engaged in wholesale and retail trading activities with the remaining shared across the different sectors of the economy (Krakah et al., 2017).

In spite of traders' contribution to the country, their plights have not received the needed attention. Government has not recognized the significant role played by traders, however turning attention to bigger businesses despite traders being the drivers of every economy. The availability of credit to traders' in the country has been the major barrier to their capacity to trade and expand their trading activities. Despite the involvements of financial institutions in the provision of trade credit to individuals who under normal circumstances will not have access to trade credit to undertake trading activities, traders face hurdles in obtaining credit for trade because they typically have less or no collateral, guarantees and source of income that makes them eligible to obtain credit from financial institutions. According to Tenkorang et al. (2016), in Ghana, the ability of traders to access trade credit is largely due to the individuals' ability in repaying back a loan taken. Hence, it must be emphasized that in determining the contribution of traders to economic development and economic growth, access to trade financing (credit) can be a vital factor. However, the potential of traders in the country has not been recognized due to the restraint under which they function.

The worries of traders' not having access to credit for their trading activities in the real world has been extensively communicated in Ghana and other sub-Saharan African countries (Elum et al., 2017; Assogba et al., 2017; Kofarmata et al., 2016; Wanjiku Ndungu, 2016; Dube et al., 2015; Anang et al., 2015; Kumar et al., 2015; Nicholas, 2015; Auma \& Mensah, 2014; Ololade \& Olagunju, 2013; Dzadze et al., 2012; Diagne \& Zeller, 2001). Precisely in Ghana, nevertheless research in this area is not enormous in relation to traders' access to credit, though some studies have been conducted. However, to the best of the researcher's knowledge, the emphasis has mainly been on access to credit by: vegetable growers, farmers (rice farmers and cocoa farmers) and Fishermen (see for example Denkyirah et al., 2016; Adams, 2015; Abunyuwah et al., 2013; Acquah \& Abunyuwah, 2011; Ackah \& Vuvor, 2011; Avortri et al., 2013; Akudugu et al., 2009). The following researchers have made enormous contributions in the field pertaining to access to credit by SMES (small and medium scale enterprises) in Ghana but not on study specific such as traders, farmers and fishermen's etc. (Abor \& Biekpe, 2006, 2007; Ardic et al., 2012; Aryeetey, 1998; Quartey, 2003; Quartey et al., 2017; Ackah \& Vuvor, 2011; Avortri et al., 2013). Regarding studies relating to access to credit by Traders only, Acheampong (2011) conducted a study in the Mfantseman Municipality of the Central Region on the determinants of access to credit by retail women. Acheampong (2011) focused only on women (female), ignoring that their counterparts men (male) also engage in retail trading in the country.

It must be stressed that in view of financial institutions willingness to provide credit fa- 
cilities to traders, there is the likelihood that educational literacy level of traders can play a vital role in their quest of accessing credit from these financial institutions of which this study seek to unravel the significant role these variables play in traders' access to credit. However, given the pursuit of access to credit by traders, very little is known on the determinants of traders' access to credit in Ghana. Nonetheless, regarding the educational literacy level of traders issues in Ghana, there is a probability that literacy level can influence credit access in the formal financial institutions. For instance, with regards to literacy level, studies have shown that education is said to be a foremost factor that influence the decision to participate in and access credit from formal financial institutions (see for example Ayamga et al., 2006; Anggraeni, 2009). In this regard the impact of literacy level on access to credit can better be analyzed when they are in categorizes. Notwithstanding, quite a number of Past Studies on Ghana (see Akudugu et al., 2009; Dzadze et al., 2012; Abunyuwah et al., 2013) measures the educational literacy level of respondents as continuous and this makes it difficult in identifying the category of respondents with educational literacy level that have a higher or least chance of accessing credit from financial institutions .Moreover, regarding the laborious paper documentation with credit access from formal financial institutions, there is the possibility that educational literacy level of traders can play a key role in credit access (Tenkorang et al., 2016). Given this, for policy purposes it is vital to look at the educational level in categories of which the current study seeks to consider.

The main objective of the study is to determine the factors behind trader's access to credit in Ghana. This study is significant in that; it's aimed at making at least two important contributions to literature. Firstly, the study provides new empirical evidence on some key determinants of traders' access to credit. Secondly, regarding the limited study relating to research in the area of factors behind traders' access to credit in Ghana, the current research provides new evidence in the area relating to traders' access to credit in financial institutions which have not been given much attention in previous studies in Ghana. Thirdly, compared to previous studies on Ghana, the present study uses a larger sample size for analysis which enhances the generalization of the results for effective policy purposes. Fourthly investigating the determinants of traders' access to credit among more than two different kinds of financial institutions. Lastly, the study focus attention on whether educational literacy level play a key role in determining traders' access to credit.

The remaining parts of the paper are structured as follows. What follows is devoted to review of related literature. Section three focuses on the methodology employed in this paper whereas section four presents the empirical results and discussion. Conclusions and policy suggestions are offered in the final section of the paper.

\section{Literature review}

There is a widespread and rich literature on what determines access to credit from financial institutions and the debates continue to expand. This section of the paper reviews some of the literature.

In Pakistan, Chandio et al. (2017) examines farmers' access to credit using probit regression as the estimation technique. The study uses 300 rural household farmers. The study finds that, gender, household size, educational level, farming experience, farm size, income, and availability of collateral have positive effect on farmers' access to credit, whereas age has a negative but insignificant effect on the farmers' access to credit. Elum et al. (2017) examines the demand for institutional credit among arable crop farmers in rivers state, Nigeria. The study applies probit estimation technique to 120 arable crop farmers. The study result 
reveals that, inadequate personal fund, unacceptable physical collateral and high transaction cost are the challenges farmers encounter in their demand for institutional credit. Further, the study reveals that demand for credit is significantly influenced by gender.

Employing logit as the estimation technique, Assogba et al. (2017) examine the determinants of credit access by smallholder farmers in North-East Benin. The study uses 120 smallholder farmers. The study reveals that, number of years of schooling, literacy, membership, guarantor, collateral and interest rate are the factors that determines smallholder farmer's access to credit. Further, the study finds a positive association between years of schooling, literacy, membership and guarantor with access to credit whereas a negative association for collateral security, interest rate and access to credit.

In Kenya, Nicholas (2015) examines the factors influencing small scale women traders' access to microcredit. The study employs descriptive statistics and uses 192 small scale women traders. The study finds that accessing of credit for starting an enterprise and lack of tangible collateral security are the major constraints by small scale women traders in accessing credit. Similarly, Odu et al. (2011) examines the determinant of rice farmer's access to credit in Niger state, Nigeria. The study uses 373 farmers and employs multinomial logit estimation technique to the data set. The study reveals that, access to formal and informal credit is significantly influenced by farmer's experience, income of farmer's from rice farming, gender, duration of village residency, and expenses on fertilizer inputs. Again in Kenya, Kamau (2008) examines the critical factors that affect the accessibility of credit services by small- scale tea farmers. The study employs descriptive statistics to 50 data points The study reveals that farmers' lack of understanding of credit services and product and lack of collateral are the main factors that affect credit access by small - scale tea farmers.

Employing probit estimation technique, Denkyirah et al. (2016) examine the factors influencing smallholder rice farmers' access to credit in the Upper East, Ghana. The study uses 140 rice farmers. The results from the study reveal that, age, marital status, membership of farmer based organization, extension visit, record keeping and farm income are the significant variables that influenced rice farmers' access to credit. Further results show that, age and farm income negatively and positively influenced farmers' access to credit whereas marital status, member of farmer based organization, record keeping and extension visit positively influenced farmers' access to credit. Adams (2015) examines the factors influencing access to credit by vegetable farmers of north and south Dzorwulu in Ghana. The study uses 152 farmers and employs probit estimation technique to the data set. The study finds that gender, source of credit, and awareness of land ownership are significant in influencing vegetable farmers' access to microcredit. Employing logistic regression estimation technique, Abunyuwah et al. (2013) investigate smallholders' farmer's access to formal credit and constraints in the Nzema east municipal, Ghana. The study uses 80 farmers (both crop and fish farmers) in the Nzema east municipal, Ghana. The study reveals that income levels, age, education, family size, distance to the financial source, farming experience, and credit awareness level significantly influence farmer's access to formal credit. Similarly, Dzadze et al. (2012) examine the factors determining access to formal credit by smallholder farmers in the Abura Asebu Kwamakese, Ghana. Employing binary logistic regression estimation to 100 data points the study finds that saving habit of farmers, extension contact, and level of education of smallholder farmers' influence farmers' access to credit significantly and positively. Acheampong (2011) investigate the determinants of access to credit by 
women retail traders in the Mfantseman municipality, Ghana. The study uses 196 respondents for the study and applied the logistic regression estimation technique as a method of analysis. The study reveals that, level of education (specifically junior and senior high school education), collateral requirement, interest rate, years of affiliation with financial institution, and savings account significantly determines access to credit by women retail traders in the Mfantseman municipality, Ghana. Again in Ghana, Akudugu et al. (2009) examine the extent of women farmer's access to credit from rural banks in the Upper East, Ghana. The study uses 200 women farmers and applied Tobit regression estimation technique. The study finds that factors influencing women farmers' extent of access to credit are age, interest rates, farm size, association membership and formal education.

From the above empirical review: both outside and on Ghana, it is observed that, most of the study focuses on factors influencing farmers access to credit see (see for instance Chandio et al., 2017; Odu et al., 2011; Assogba et al., 2017; Akudugu et al., 2009; Denkyirah et al., 2016; Adams, 2015) whereas quite a number of studies focuses on factors determining traders (women) access to credit (Acheampong, 2011). This present study however, focuses attention on the factors that determines traders access to credit in Ghana and establish whether educational literacy level is a key determinants of traders' access to credit. Secondly, the present study uses a relatively larger sample size (350 sampled respondents) for its analyses as compared to past studies on Ghana that used less than 250 respondents (see Acheampong, 2011; Akudugu et al., 2009; Adams, 2015; Denkyirah et al., 2016). Doing so, is of a particular importance to stakeholders, policy makers, managements of financial institutions among others as it will assist them to know the key factors that determines traders access to credit with a focus on the educational literacy level of respondents and hence enable them devise strategies in dealing with their Customers in given out credit facilities to them. Hence the present study will contribute to knowledge and literature specifically focusing on the factors that determine traders' access to credit in Ghana focusing on the role educational literacy level play.

\section{Empirical methodology}

This section presents and discusses the data used in this study, empirical model of estimation and description of the variables used for the study.

\subsection{Data and estimation strategy}

The present study relies mainly on primary data and employs binary probit as the estimation technique. The data for the study is obtained by administering questionnaires to a sample of 350 randomly selected traders who operate different type of financial institutions account using purposive sampling technique in selecting traders of Kumasi Metropolis, Ghana. The study used both self-administered and face-to-face interview for the data collection. These two methods are used in order to avoid any potential biasedness in the study: not overlooking borrowers of financial institutions who cannot read, understand and write in English language.

The tools for analysis in this study are descriptive statistics and binary probit estimation technique. Also in order to ensure that the information obtained for the study is reliable, Cronbach alpha coefficient is used to test the reliability of the instruments. The binary probit estimation technique is employed given the dichotomous nature of the dependent variable (access to credit: value of 1 for having access to credit and 0 for not having access to credit) from financial institutions. 


\subsection{Model specification}

Past studies have employed numerous estimation techniques including probit regression technique (see for example Chandio et al., 2017; Denkyirah et al., 2016), logistic regression (Abunyuwah et al., 2013; Assogba et al., 2017), tobit regression (Akudugu et al., 2009) and multinomial logit regression (Odu et al., 2011) to study the determinants of access to credit. In this present study, the dependent variable (access to credit) is binary and for that matter the study used the binary probit regression as the estimation technique following the empirical work of Chandio et al. (2017) who adopted similar technique for estimation. The functional and estimable forms of the model are specified in equation (1) and (2) respectively as:

$$
\begin{gathered}
A C=f(G E N, A G E, E D U, H S, \\
B E X P, S I, C S) \\
A C_{t}=\beta_{0}+\beta_{1} G E N+\beta_{2} A G E+ \\
\beta_{3} E D U+\beta_{4} H S+\beta_{5} B E X P+ \\
\beta_{6} S I+\beta_{7} C S+\mu_{t}
\end{gathered}
$$

From equation (2), the dependent variable is having access to credit $(A C)$ and the explanatory variables are gender $(G E N)$, age $(A G E)$, educational literacy level of respondents $(E D U)$, household size $(H S)$, business experience $(B E X P)$, source of income $(S I)$, and collateral security $(C S)$ used in accessing loan. $\beta_{0}$ is the constant term, the remaining $\beta_{i}$ 's $($ wherei $=1,2,3, \ldots, 7)$ are the coefficients of the respective independent variables and $\mu_{i}$ is the error term. In order to give more meanings to the regression results, the average marginal effects of the regressors are used as Greene (2000) contends.

\subsection{Variable description}

Access to credit which is the dependent variable in this study is defined as the ability of the respondent to access credit from financial institutions (microfinance, rural banks, and savings and loan institutions). Specifically, the respondents are asked "Did you have access to credit? and the response is either "Yes" or "No". Therefore, if the response from the respondent is "Yes", then he or she have access to credit and if "No" it is regarded as have no access to credit. Thus the dependent variable takes the value 1 for having access to credit and 0 for not being able to access credit (have no access to credit).

Regarding the independent variables, gender is categorical and hence treated as a dummy variable with the reference category being male. Empirically, studies by Chandio et al. (2017) and Assogba et al. (2017) revealed that gender (either being male or female) has a positive association with access to credit. Hence a positive relationship between gender of respondents and traders' access to credit is expected.

Age has four categories: 18-25 years, 26-40 years, 41-55 years and above 56 years with 18-25 years being the reference category. Age is expected to have a negative or positive effect on being able to access credit since its effect is uncertain. Regarding educational literacy level, it has four categories (no education, primary/JHS (Junior High School) education, secondary/SHS (Senior High School) and tertiary education) with the reference group being the uneducated (no education). Education (primary/JHS education, secondary/SHS and tertiary education) is expected to have a positive or negative effect on been able to access credit since its effect is uncertain. Studies by Assogba et al. (2017) has revealed that traders who have higher level of education, for instance, secondary education and tertiary level of education are more likely to access credit than their counterparts. This is because they are in a better position to accounts for the credit they took in terms of better records keeping of their daily business sales activities and their ability to read and write. For this reasons, positive association is expected for traders who have higher level 
of education and credit access.

Regarding source of income. Source of income is a categorical variable (have source of income or otherwise) with have no source of income being the reference group. Source of income is expected to have a positive impact on access to credit. This is because credit is granted based on the fact that individuals have source of income and possibly other source of income. However, when individual has a source of income there will be more likelihood that being able to access credit will be high. On the other hand, collateral security is measured as a categorical variable (accessing credit by collateral security or otherwise) with not accessing credit by means of a collateral security being the reference category. This variable (collateral security) is expected to have a positive impact on access to credit since borrowers who accessed credit by means of collateral have more likelihood being granted credit.

Regarding the remaining variables: Household size has four categories: 1-2 household size, 3-4 household size, 5-6 household size and above 6 household size with 1-2 household size being the reference category. Household size is expected to have a negative or positive effect on being able to have access to credit. Finally, Business experience has five categories: less than one-year experience, 1-5 years' experience, 610 years' experience, 11-15 years' experience and above 15 years' experience with less than one year being the reference category. Business experience is expected to have a positive effect on being able to access credit. It must be emphasized that, all variables in this study are categorical and hence treated as dummy variables.

\section{Results and discussions}

This section presents the analyses and presentation of the findings from the study. it comprises the descriptive statistics of the variables probit estimation results and the test for reliability.

\subsection{Descriptive statistics}

The descriptive statistics of the respondents (traders) in the study are reported in Table 1.

The statistics in Table 1 shows that out of the 350 respondents who applied for credit from financial institutions, 127 representing 36.29 percent have access to credit whereas 223 representing 63.71 percent had no access to credit. Thus majority of respondents (traders') have no access to credit.

Further results show that male respondents are 151 while female respondents are 199 representing 43.14 percent and 56.86 percent respectively. This implies that female respondents are more than their male counterparts. Again, Table 1 reveals that respondents who have no level of education constitute 17.71 percent whilst those with primary education represent 13.71 percent. With regard to secondary and tertiary education, 48.57 percent and 22 percent respondent have secondary and tertiary level of education respectively. Regarding business experience, the study finds that 4 (1.14 percent) respondents have less than one years' experience in business. The results further show that, respondents who have 1-5 and 6-10 years' business experience represents 32.9 percent (113) and 36.5 percent (128) whereas respondents who have 11-15 and above 16 years' experience in business are 21.43 percent (75) and 8.57 percent (30) respectively. In addition, 16.29 percent (57) respondents have household size ranging 1-2. Further, 63.71 percent (166) and 28.57 percent (100) respondents have household size ranging from 3-4 and 5-6 respectively. Also, 7.71 percent (27) respondents have household size above 6 .

Results from Table 1 further reveals that in terms of respondents age, 11.7 percent (41) and 41.14 percent (144) are between the age groups of 18-25 years and 26-40 years respectively whilst 37.43 percent (133) are within the age group of 41-55years. In addition, 
Table 1: Descriptive statistics of respondents

\begin{tabular}{lcc}
\hline Socio-demographics & Frequency & Percentage \\
\hline Gender & 151 & 43.14 \\
Male & 199 & 56.86 \\
Female & & \\
Age & 41 & 11.71 \\
18-25 years & 144 & 41.14 \\
26-40 years & 131 & 37.43 \\
41- 55 years & 34 & 9.71 \\
Above 56 years & & \\
Education & 55 & 17.71 \\
No education & 48 & 13.71 \\
Primary education & 170 & 48.57 \\
Secondary education & 77 & 22 \\
Tertiary education & & \\
Household size & 57 & 16.29 \\
1-2 household size & 166 & 63.71 \\
3-4 household size & 100 & 28.57 \\
5-6 household size & 27 & 7.71 \\
Above 6 household size & & \\
Business experience & 4 & 1.14 \\
Less than one year & 113 & 32.39 \\
1-5 years & 128 & 36.57 \\
6-10 years & 75 & 21.43 \\
11-15 years & 30 & 8.57 \\
Above 16 years & & \\
$\begin{array}{l}\text { Source of income } \\
\text { Have source of income }\end{array}$ & 142 & 40.57 \\
Have no source of in- & 208 & 59.43 \\
come & & \\
Collateral security & & \\
Access credit by collat- \\
eral
\end{tabular}

9.71 percent (34) of the respondents are within the age group of 56 years and above. This implies that, as regards to the age of the respondents, majority of them are in the age group of 26-40 years. Regarding source of income, 40.57 percent (142) respondents have source of income whilst 59.43 percent (208) respondents have no source of income. Finally, with respect to collateral security used in accessing credit, 147 representing 42 percent of the respondents accessed credit by means of collateral security whilst 203 representing 58.0 percent of the respondents did not access credit by means of collateral security respectively.

\subsection{Analysis of correlation results}

In examining the association among the variables, correlation analysis was performed. Table 2 presents the correlation results of the constructed variables.

Results from the correlation analyses of the variables reveal that access to credit has a positive and significant relationship with, education, source of income and availability of collateral security. Further, a negative association was found on, gender, household size, and business experience but insignificant whilst a positive association was found between age and access to credit but insignificant. Again, the results in Table 4 reveal that multicollinearity is not an issue in this study because the correlation coefficients among the explanatory variables are all less than 0.5.

\subsection{Regression results}

In achieving the objective of the study, equation (2) is estimated and the results are presented in Table 3.

As expected, the results in Table 3 show that there is a positive relationship between respondents who have primary education, secondary education, and tertiary education variables and access to credit even though only respondents who have tertiary level of education is significant at 5 percent level of significance. Given the positive relationship for all educational categories and access to credit implies that, as the level of an individual's education increases the likelihood of having access to credit also increases. However, though majority of the respondents are found in the secondary education level category, it could be that majority of them are unable to read and keep proper records regarding their business activities hence their denial of credit application by financial institutions. Therefore, using the marginal effect, the results show that on average, borrowers who 
Table 2: Correlation results

\begin{tabular}{lcccccccc}
\hline Variable & $\mathrm{AC}(1)$ & $\mathrm{GEN}(2)$ & $\mathrm{AGE}(3)$ & $\mathrm{EDU}(4)$ & $\mathrm{HS}(5)$ & $\mathrm{SI}(6)$ & $\mathrm{BEXP}(7)$ & $\mathrm{CS}(8)$ \\
\hline $\mathrm{AC}(1)$ & 1.0000 & & & & & & & \\
GEN(2) & -0.0505 & 1.0000 & & & & & & \\
$\mathrm{AGE}(3)$ & 0.0121 & 0.0152 & 1.0000 & & & & & \\
$\mathrm{EDU}(4)$ & $0.0202^{*}$ & $-0.0251^{*}$ & -0.0462 & 1.0000 & & & & \\
$\mathrm{HS}(5)$ & -0.0014 & 0.0129 & $0.0325^{*}$ & -0.0458 & 1.0000 & & & \\
$\mathrm{SI}(6)$ & $0.04514^{*}$ & -0.0103 & 0.0301 & $0.0253^{*}$ & -0.0237 & 1.0000 & & \\
$\mathrm{BEXP}(7)$ & -0.0438 & 0.0463 & $0.0343^{*}$ & $-0.0381^{*}$ & $0.0385^{*}$ & 0.0080 & 1.0000 & \\
$\mathrm{CS}(8)$ & $0.0404^{*}$ & -0.0452 & -0.0025 & 0.0311 & -0.0262 & $0.0139^{*}$ & -0.0436 & 1.0000 \\
\hline
\end{tabular}

Source: Authors.
Note: $*$ denotes that the correlation is significant at $1 \%$.

have tertiary education level are 20.53\% more likely to have access to credit from financial institutions successfully relative to those who have no level of education. This can be attributed to the fact that, trading activities requires handling of large volumes of money and proper records keeping on daily basis and financial institutions prefer individuals with some level of educational background, preferably tertiary level of education, because it is believed that they can keep better records of money gotten and give proper accounts when they are asked to do so as compared to their counterparts who have no or little knowledge when it comes to rendering of account and book keeping given their level of education (no education). This is in line with the findings of Dzadze et al. (2012); Acheampong (2011); Chandio et al. (2017). However, the above therefore implies that Educational literacy level play a vital role in the quest of accessing credit from financial institutions among respondents with tertiary level of education than their counterparts. From the above empirical results on education level, it has been shown clearly that it is said to be a foremost factor that influence the decision to participate in and access credit from formal financial institutions as recognized by Ayamga et al. (2006) and Anggraeni (2009).

Regarding Household size, results show that there is a positive relationship between all the household size variables and access to credit even though only respondents with household size of 3-4 years is significant. Therefore, using the marginal effect, the results show that on average, respondents within the household size of 3-4 are $19.39 \%$ more likely to have access to credit successfully comparative to those with household size of 1-2. This can be that, relatively larger household size has higher demand for credit to increase trading efficiency, hence more likely to have access to credit comparative to those with smaller household size. The findings confirm similar studies by Vaessen (2001).

As regards source of income, the results reveal a negative relationship between source of income and access to credit and is statistically significant at 5 percent. This implies that respondents' who have source of income and access credit from financial institutions have lower probability of having access to credit from financial institutions. Specifically, the marginal effect's value shows that haven source of income on average decreases the likelihood of haven access to credit by 9.93 percent relative to those who have no source of income. Even though it contravenes our expectation, it could be that, financial institutions (microfinance, savings and loans, and rural banks) specifically in given out credit, focus mostly on individuals' who have no set up capital to start-up business than their counterparts, however given the nature of operation and goal of (microfinance, savings and loans, and rural banks) in helping to reduce poverty and give help to poor households in other to raise their income levels. They tend to give help to individuals' who have no source of income as compared 
Table 3: Estimated Probit regression results on determinants of traders access to credit

\begin{tabular}{|c|c|c|c|c|}
\hline Variables & Coefficient & $\begin{array}{l}\text { Standard } \\
\text { Error }\end{array}$ & $\begin{array}{l}\text { Average } \\
\text { Marginal } \\
\text { Effect }\end{array}$ & P-Value \\
\hline Gender(Male) & & & & \\
\hline $\begin{array}{l}\text { Female } \\
\text { AGE(18-25years) }\end{array}$ & -0.0938 & 0.1678 & -0.0345 & 0.562 \\
\hline AGE-26-40yrs & -0.0165 & 0.2838 & -0.0062 & 0.967 \\
\hline AGE-41-55yrs & 0.2892 & 0.3153 & 0.1036 & 0.389 \\
\hline $\begin{array}{l}\text { AGE-Above } 56 y r s \\
\text { EDU(No Education) }\end{array}$ & -0.2817 & 0.4152 & -0.0963 & 0.485 \\
\hline Primary & 0.0038 & 0.2957 & 0.0017 & 0.987 \\
\hline Secondary & 0.2165 & 0.2187 & 0.0345 & 0.791 \\
\hline $\begin{array}{l}\text { Tertiary } \\
\text { HHSIZE(1-2) }\end{array}$ & 0.5358 & 0.2781 & 0.2053 & $0.025^{* *}$ \\
\hline $3-4$ & 0.5897 & 0.2085 & 0.1939 & $0.007 * * *$ \\
\hline $5-6$ & 0.2864 & 0.3535 & 0.0714 & 0.612 \\
\hline Above 6 & 0.5695 & 0.3444 & 0.2365 & 0.106 \\
\hline $\begin{array}{l}\text { BUSEXP(less than } 5 \\
\text { years ) }\end{array}$ & & & & \\
\hline $6-10$ years & 0.8668 & 0.3925 & 0.2877 & $0.021^{* *}$ \\
\hline 11-15 years & 0.2035 & 0.4268 & 0.0604 & 0.788 \\
\hline Above 16 years & 0.9408 & 0.9478 & 0.2260 & 0.187 \\
\hline $\begin{array}{lcr}\text { SOURCE } & \text { OF } & \text { IN- } \\
\text { COME } & \text { (Have } & \text { no } \\
\text { income source) } & \end{array}$ & & & & \\
\hline $\begin{array}{l}\text { Have source of income } \\
\text { Collateral Security (No } \\
\text { collateral) }\end{array}$ & -0.3195 & 0.1641 & -0.0993 & $0.029 * *$ \\
\hline Collateral & 0.8571 & 0.1739 & 0.2909 & $0.000^{* * *}$ \\
\hline Constant & -1.3147 & 0.4458 & - & - \\
\hline Number of Observation & 350 & & & \\
\hline LR $\operatorname{chi} 2(18)$ & 85.48 & & & \\
\hline Log pseudo likelihood & -191.6260 & & & \\
\hline Pseudo R2 & 0.1824 & & & \\
\hline Prob i chi2 & 0.0000 & & & \\
\hline
\end{tabular}

to their counterparts, hence a decrease in the likelihood of individuals' with a source of income to have access to credit than their counterparts. This finding opposes similar studies by Chandio et al. (2017) and Abunyuwah et al. (2013).

Further, as expected, the result reveals a positive relationship between collateral and access to credit and is statistically significant at 1 percent. This implies that respondents who accessed credit by means of collateral security from financial institutions have higher probability of having access to credit. Thus, the marginal effect value shows that on average, individual who accessed credit by means of collateral security are more likely to have access to credit by 29.09 percentage points than their counterparts who did not use collateral when accessing credit from financial institutions. By implication, most financial institutions give out credit facilities to individual who are able to pledge with a collateral as compared to their counterparts with the notion that failure on the part of the individual borrower in paying back the loan, the collateral will be sold to defray the loan if repayment is not successful, hence the more likelihood for individuals' who access credit with collateral to have access to credit than their counterparts. The findings are consistent with those of Chandio et al. (2017), Elum et al. (2017), Acheampong (2011), Nicholas (2015) and Assogba et al. (2017). 
Regarding business experience of the respondents, as expected, the study reveals a positive relationship for all the business experience categories and access to credit even though only respondents with 6-10 years of experience was found to be significant at 5 percent level of significance. The positive relationship implies that as one's level of experience in the business (economic activity) he/she engages in increases it increases his/her probability of accessing credit from financial institutions. Thus, the marginal effect value shows that on average, individual with 6-10 years' business experience are more likely to have access to credit by 28.77 percentage points than their counterparts. Generally, financial institutions are at a higher risk in granting loans to business starters because they tend to lack the experience among others in the line of business they intend to engage themselves in and hence this might affect their profitability and their ability to repay back the loan on time. Given this, they mostly prefer individuals who have been in business for long because they possess adequate knowledge and experience in their line of business, proper managements of risk in business, have established enough business partners, have enough startup capital among others hence have higher probability of credit access from financial institutions than their counterparts.

On the other hand, the study did not find any significant relationship between access to credit and gender, and age of the respondents. In addition, the study finds no significant relation among respondents who have primary and secondary level of education and respondents who have household size of 5-6 and above 6. Also, though insignificant, as expected, the results show a negative relationship between gender and access to credit. Further, there was a positive and negative relationship between age variable and access to credit. This shows that, gender and respondents within the household size of 5-6, above 6 , and re- spondents who have primary and secondary educational level do not determine access to credit among respondents of financial institutions in the Kumasi Metropolis of Ghana.

\subsection{Reliability test results}

Further, as stated earlier under section 3.1 , the validity of the results obtained depends on the assumption that the instrument used for data collection is reliable.

From Table 3, the result obtained from the reliability test reveals that, the average alpha value of the variables used in the study is 0.7345 (73 percent) indicating that the instrument used for data collection is reliable and there is high internal consistency among the variables. It also implies that same or similar results can be obtained when same instrument is administered at another period. Thus, according to Field (2009), Cronbach alpha values for all independent variables should be greater than 0.7 (70 percent) and the result from that of the present study is greater than the proposed alpha value.

Table 4: Reliability test results

\begin{tabular}{lc}
\hline $\begin{array}{c}\text { Average interitem } \\
\text { covariance }\end{array}$ & $\begin{array}{c}\text { Scale reliability coefficient } \\
\text { (alpha value) }\end{array}$ \\
\hline 0.0798 & 0.7345 \\
\hline Source: Authors. &
\end{tabular}

\section{Conclusion and recommendation}

This study investigates the factors that determine traders' access to credit in Ghana: Does Educational Literacy level matter? The study relies on primary data and employs descriptive statistics and the binary probit regression estimation technique for the analysis.

The results show that there is a significant positive relationship between educational literacy level and access to credit. Again, the study has establish that among the respondent with the various level of educational literacy level, only respondents 
who have tertiary level of education was found to be significant and hence are more likely to have access to credit from financial institutions compared to their counterparts. This is due to the fact that, it is believed that they can keep better records of money gotten and give proper accounts when they are called upon to render their account transactions due to their ability to read and write and mostly higher literacy level of education requires better knowledge in terms of exposure to financial institutions operations and management. In addition, in the quest to open a bank account with their level of education they make the process very simple and easier for managements than their counterparts as a result of additional training they receive in schooling regarding financial transactions. In addition, a negative and significant relationship is found between source of income and access to credit. Further, the results reveal that there is a significant positive relationship between collateral security and respondents who have household size ranging from 3-4, and access to credit. Again, study reveals that there is a positive and significant relationship for respondents with 6-10 years of business experience and access to credit. On the other hand, the present study did not find any significant relationship between age, gender and access to credit. In addition, the study did not find any significant relation among respondents who have primary and secondary level of education, respondents who have household size ranging from 5-6 and above 6 , and access to credit.

Hence, to improve traders' access to credit, the study recommends that financial institutions need to restructure their procedures and financial mechanism that requires collaterals in the form of (buildings, family land, and cars) that could help traders' to easily access credit. Also, to make sure that all traders' have easy access to credit without placing much emphasis on the level of education, financial institutions should consider educating traders' to have the needed knowledge about account and record keeping patterning to their line of business since education is said to be a foremost factor that influence the decision to participate in and access credit from formal financial institutions. In addition, its recommended that financial institutions should encourage traders to upgrade their educational level, since this will enhance their basic knowledge not only on their trading activities but also on financial transactions. Further, the study recommends that traders with source of income should be considered as they would need extra income to help expand their trading activities that requires huge some of amount.

\section{References}

Abor, J., \& Biekpe, N. (2006). Small business financing initiatives in ghana. Problems and Perspectives in Management, 4(3), 69-77. https://businessperspectives.org/images/ pdf/applications/publishing/templates/ article/assets/838/PPM_EN_2006_03_Abor .pdf.

Abor, J., \& Biekpe, N. (2007). Small business reliance on bank financing in ghana. Emerging Markets Finance and Trade, 43(4), 93-102. doi:10.2753/REE1540-496X430405

Abunyuwah, I., Blay, J. K., \& Ghana, A. (2013). Accessibility constraints of small-scale fish farmers to formal credit in the nzema east municipality. Journal of Economics and Sustainable Development, 4(1), 128-133. https://www.academia . edu/download/39254407/4106-6125-1-PB.pdf.

Acheampong, R. (2011). Determinants of access to credit by women retail traders in the mfantseman municipality of the central region (Doctoral dissertation, University of Cape Coast). https://erl.ucc.edu.gh/jspui/ handle/123456789/1106.

Ackah, J., \& Vuvor, S. (2011). The challenges faced by small \& medium enterprises (smes) in obtaining credit in ghana (Master's thesis, Blekinge Institute of Technology, School of Management). https://www.diva-portal.org/smash/ record.jsf?pid=diva2\%3A829684\&dswid=-6564.

Acquah, H. D., \& Abunyuwah, I. (2011). Logit analysis of socio-economic factors influencing people to become fishermen in the central region of ghana. Journal of Agricultural Sciences, Belgrade, 56(1), 55-64. doi:10.2298/JAS1101055A

Adams, D. (2015). Determinants of microcredit access and f farmers' investment in small scale peri-urban agriculture: A case study of dzorwulu 
vegetable farmers (Doctoral dissertation, University of Ghana). http://ugspace.ug.edu.gh/ handle/123456789/8448.

Akudugu, M., Egyir, I. S., \& Mensah-Bonsu, A. (2009). Access to rural bank credit in ghana: The case of women farmers in the upper east region of ghana. Ghana Journal of Development Studies, 6(2). doi:10.4314/gjds.v6i2.61396

Anang, B. T., Sipilainen, T., Backman, S., \& Kola, J. (2015). Factors influencing smallholder farmers access to agricultural microcredit in northern ghana. African Journal of Agricultural Research, 10(24), 2460-2469. doi:10.5897/AJAR2015.9536

Anggraeni, L. (2009). The function of social networks to credit access and offfarm work: a case of coconut farmers in rural areas of riau province, indonesia. Journal of International Society for Southeast Asian Agricultural Sciences, 15(1), 6376. https://pdfs.semanticscholar.org/e29b/ e86b8d36941882e5091acb546f13915e5bd7. pdf.

Ardic, O. P., Mylenko, N., \& Saltane, V. (2012). Access to finance by small and medium enterprises: a cross-country analysis with a new data set. Pacific Economic Review, 17(4), 491-513. doi:10.1111/j.1468-0106.2012.00596.x

Aryeetey, E. (1998). Informal finance for private sector development in africa (Economic Research Papers No. 41). Abidjan: The African Development Bank. https://www.afdb.org/fileadmin/ uploads/afdb/Documents/Publications/ 00157616-EN-ERP-41.PDF.

Assogba, P. N., Kokoye, S. E. H., Yegbemey, R. N., Djenontin, J. A., Tassou, Z., Pardoe, J., \& Yabi, J. A. (2017). Determinants of credit access by smallholder farmers in north-east benin. Journal of Development and Agricultural Economics, 9(8), 210-216. doi:10.5897/JDAE2017.0814

Auboin, M., Bacchetta, M., Beverelli, C., D'Andrea, B., Degain, C., Keck, A., ... Zhang, R. (2016). World trade report 2016: levelling the trading field for smes (World Trade Report No. 2016). Geneva: WTO Publishing. https://www.wto.org/english/res_e/ booksp_e/world_trade_report16_e.pdf.

Auma, D., \& Mensah, P. (2014). Determinant of credit access and demand in tigray region, ethiopia (Master's thesis, Norwegian University of Life Sciences, School of Economics and Business). https://nmbu.brage.unit.no/ nmbu-xmlui/handle/11250/217416.

Avortri, C., Bunyaminu, A., \& Wereko, T. (2013) Factors that hinder access to credit by small and medium scale enterprises despite the financial sector liberalization in ghana. International Journal of Management Sciences, 1(10), 386-404. https://www. academia.edu/download/ 33869344/Paper_3.pdf.

Ayamga, M., Sarpong, D., \& Asuming-Brempong, S. (2006). Factors influencing the decision to participate in micro-credit programme: an illustration for northern ghana. Ghana
Journal of Development Studies, 3(2), 57-65. doi:10.4314/gjds.v3i2.35043

Chandio, A. A., Jiang, Y., Wei, F., Rehman, A., \& Liu, D. (2017). Famers' access to credit: Does collateral matter or cash flow matter?-evidence from sindh, pakistan. Cogent Economics \& Finance, 5(1), 1-13. doi:10.1080/23322039.2017.1369383

Denkyirah, E. K., Adu, D. T., Aziz, A. A., Denkyirah, E. K., \& Okoffo, E. D. (2016). Analysis of the factors influencing smallholder rice farmers' access to credit in the upper east region of ghana. Asian Journal of Agricultural Extension, Economics \& Sociology, 10(4), 1-11. doi:10.9734/AJAEES/2016/24768

Diagne, A., \& Zeller, M. (2001). Access to credit and its impact on welfare in malawi (Research Report No. 116). Washington D.C.: International Food Policy Research Institute.

Dube, L., Mariga, T., \& Mrema, M. (2015). Determinants of access to formal credit by smallholder tobacco farmers in makoni district, zimbabwe. Greener Journal of Agricultural Sciences, 5(1), 34-42. doi:10.15580/GJAS.2015.1.011515003

Dzadze, P., Aidoo, R., \& Nurah, G. (2012). Factors determining access to formal credit in ghana: A case study of smallholder farmers in the abura-asebu kwamankese district of central region of ghana. Journal of Development and Agricultural Economics, 4(14), 416423. https://academicjournals.org/journal/ JDAE/article-abstract/976722E44653.

Elum, Z. A., Ugwuja, V. C., \& Ogor, J. U. (2017). Demand for institutional credit among arable crop farmers in Obio-Akpor local government area of Rivers State. Nigerian Journal of Agriculture, Food and Environment, 13(2), 99-103. http://njafe.com/njafe2017Vol13No2/ 19_Elum_et_al.pdf.

Field, A. (2009). Discovering statistics using SPSS. Sage Publication Inc.

Greene, W. H. (2000). Econometric analysis. New York: Macmillan.

Kamau, B. N. (2008). Critical factors that affect the accessibility of credit services by small-scale tea farmers (Unpublished masters project No. D61/P/8539/05). Nairobi, Kenya: University of Nairobi. http://erepository.uonbi.ac.ke/ handle/11295/63995.

Kofarmata, Y. I., Applanaidu, S. D., \& Hassan, S. (2016). Determinants of demand for credit: A conceptual review. Asian Journal of Economics and Empirical Research, 3(1), 6-10. doi:10.20448/journal.501/2016.3.1/501.1.6.10

Krakah, A., Odoom, D., Dadson, I., Kagya, J. O., Ocran, E., Ofsu-Baadu, B., ... Anyetei, A. (2017). Integrated business establishment survey report (Survey Report No. IBES II). Accra: Ghana Statistical Service. http://www2.statsghana.gov.gh/ docfiles/publications/IBES/IBESII/ IBES $\% 20$ II $\% 20$ Summary $\% 20 \% 20$ Report.pdf. 
Kumar, A., Singh, R., Jee, S., Chand, S., Tripathi, G., \& Saroj, S. (2015). Dynamics of access to rural credit in india: patterns and determinants. Agricultural Economics Research Review, 28(conf), 151-166. doi:10.5958/09740279.2015.00030.0

Mabasa, W. (2015). The impact of informal traders on the economic development of limpopo.

Nicholas, T. C. (2015). Factors influencing women small scale traders access to microcredit from microfinance institutions: A case of women in city park hawkers market, Nairobi county, Kenya (Unpublished masters project). Nairobi, Kenya: University of Nairobi. http://erepository .uonbi.ac.ke/handle/11295/90892.

Odu, O., Okoruwa, V. O., Adenegan, K. O., \& Olajide, A. (2011). Determinants of rice farmer's access to credit in Niger State, Nigeria. Journal of rural economics and development, 20(1), 820. https://pdfs. semanticscholar.org/9dc0/ e1615ca47744b78deb017d04ea4864460b0f .pdf.

Ololade, R., \& Olagunju, F. (2013). Determinants of access to credit among rural farmers in oyo state, nigeria. Global Journal of Science Frontier Research Agriculture and Veterinary Sciences, 13(2), 16-22. https://globaljournals.org/ item/1492-determinants-of-access-to-credit -among-rural-farmers-in-oyo-state-nigeria.

Poku, M., Gyamfi, S., Owusu-Kagya, J., Lamptey, A., Agbenyo, G., Marfu, J., ... Krakah, A. (2008). Ghana living standards survey report of the fifth round (Survey Report No. GLSS 5). Accra: Ghana Statistical Service. http://www2.statsghana.gov.gh/nada/ index.php/catalog/5/download/41.

Quartey, P. (2003). Financing small and medium enterprises (smes) in ghana. Journal of African Business, 4(1), 37-55. doi:10.1300/J156v04n01_03

Quartey, P., Turkson, E., Abor, J. Y., \& Iddrisu, A. M. (2017). Financing the growth of smes in africa: What are the contraints to sme financing within ecowas? Review of Development Finance, 7(1), 18-28. doi:10.1016/j.rdf.2017.03.001

Tenkorang, B., Tenkorang, F., Ujah, N., \& Ziwoya, F. (2016). Default in lending potential of small and medium enterprises: The case of ghana. African Journal of Accounting, Economics, Finance and Banking Research, 10(10). https://papers.ssrn.com/sol3/papers .cfm?abstract_id $=2884404$.

Vaessen, J. (2001). Accessibility of rural credit in northern nicaragua: The importance of networks of information and recommendation / accessibilitÉ du crÉdit rural dans le nord du nicaragua: L'importance des rÉseaux d'information et de recommandation. Savings and Development, 25(1), 5-32. http://www.jstor.org/stable/ 25830748.

Wanjiku Ndungu, C. (2016). Factors affecting credit access among small and medium enterprises in murang'a county (Unpublished masters project No. D61/74427/2014). Nairobi, Kenya: Univer- sity of Nairobi. http://erepository.uonbi.ac .ke/handle/11295/98555. 